Sains Malaysiana 47(1)(2018): 59-66

http://dx.doi.org/10.17576/jsm-2018-4701-07

\title{
Stability Assessment of Limestone Cave: Batu Caves, Selangor, Malaysia
}

(Penilaian Kestabilan Gua Batu Kapur: Batu Caves, Selangor, Malaysia)

\author{
Goh Thian Lai*, Wong Jia Mang, Abdul GHani Rafek, Ailie Sofyiana Serasa, Nur Amanina MaZlan, \\ Ainul MARDHIYAH MOHD RAZIB, AZIMAH HuSSIN, LEE KHAi ERN \& TUAN RUSLi MOHAMED
}

\begin{abstract}
The limestone hill of Batu Caves is slowly being turned into a recreation park for slope climbing, base jumping and cave exploring. Quantitative assessment on the stability of the cave is essential to ensure the safety of tourists and visitors. The aim of this study was to quantitatively assess the stability of Gua Damai, Batu Caves, Selangor, Malaysia by using the $Q$ system for rock mass classification, together with other factors such as cave width and thickness of the cave roof. The stability of the limestone cave wall was evaluated using Slope Mass Rating (SMR). A discontinuity survey conducted along the slopes beneath the opening of the cave showed that the rock mass comprised of four major joint sets labeled as $\mathrm{J1}, \mathrm{J} 2, \mathrm{J3}$, and $\mathrm{J} 4$ with the dip directions and angles of $110^{\circ} / 73^{\circ}, 325^{\circ} / 87^{\circ}, 243^{\circ} / 39^{\circ}$ and $054^{\circ} / 30^{\circ}$, respectively. The result of kinematic analysis showed that the dip direction/dip angle of a potential wedge failure was $051^{\circ} / 59^{\circ}$. By referring to the ratio of cave roof thickness with cave width, the results showed that the cave is stable. Based on the relationship between $Q$ system and the cave width, the stabilities of Section 4 of Gua Damai is stable while Section 1, 2, 3, 5, 6, 7 and 8 require supports. Based on SMR, the cave walls stability at Portion $c, d$, and $f$ were not stable while Portion $a, b, e$ and $g$ were stable. Overall, the most stable part of the cave is Section 4 followed by Sections 5 and 2. Sections 1, 3 and 8 are moderately stable while Sections 6 and 7 have poor stability.
\end{abstract}

Keywords: Cave stability assessment; limestone; Slope Mass Rating (SMR); Q system

ABSTRAK

Bukit batu kapur Batu Caves dijadikan sebagai taman rekreasi secara perlahan perlahan bagi aktiviti mendaki cerun, lompat tinggi dan penerokaan gua. Penilaian kuantitatif kestabilan gua adalah penting bagi menjamin keselamatan pelancong dan pengunjung. Tujuan kajian ini adalah untuk menilai kestabilan Gua Damai, Batu Caves, Selangor, Malaysia secara kuantitatif menggunakan Sistem Q untuk pengelasan jasad batuan dan faktor lain seperti kelebaran gua dan ketebalan bumbung gua. Kestabilan dinding gua dinilai menggunakan Perkadaran Jasad Cerun (SMR). Satu survei ketakselanjaran telah dijalankan di sepanjang cerun di bawah bukaan gua menunjukkan jasad batuan mengandungi empat set kekar utama iaitu J1, J2, J3 dan J4 dengan arah dan sudut kemiringan masing-masing bernilai $110^{\circ} / 73^{\circ}$, $325^{\circ} / 87^{\circ}, 243^{\circ} / 39^{\circ}$ dan $054^{\circ} / 30^{\circ}$. Keputusan analisis kinematik menunjukkan arah dan sudut kemiringan kegagalan baji yang berpotensi ialah $051^{\circ} / 59^{\circ}$. Merujuk kepada nisbah antara ketebalan bumbung gua dengan kelebaran gua, keputusan menunjukkan bahawa gua adalah stabil. Berdasarkan kepada hubungan antara sistem Q dan kelebaran gua, Bahagian 4 Gua Damai adalah stabil manakala Bahagian 1,2, 3, 5, 6, 7 dan 8 memerlukan sokongan. Berdasarkan SMR, kestabilan dinding gua pada Bahagian $c, d$, dan $f$ adalah tidak stabil manakala Bahagian $a, b, e$ dan $g$ adalah stabil. Secara keseluruhan, bahagian gua yang paling stabil ialah Bahagian 4 diikuti oleh Bahagian 5 dan 2. Bahagian 1, 3 dan 8 adalah sederhana stabil manakala Bahagian 6 dan 7 mempunyai kestabilan yang rendah.

Kata kunci: Batu kapur; penilaian kestabilan gua; Perkadaran Cerun Batuan (SMR); sistem Q

\section{INTRODUCTION}

Geological hazards such as landslides, rockfalls, subsidence, sinkholes and the collapse of limestone bedrock are common engineering problems in tropical countries due to the quick process of dissolution by acidic rainwater. Hatzor et al. (2002) suggested that the collapse of the cave he studied was caused by failure of the rock mass, movement of the cave walls and roof of the cave. However, the hazards of limestone caves are difficult to estimate. Waltham (2002) and Waltham and Fookes (2003) assessed the stability of a limestone cave by using Q System and the width of cave and also suggested that the cave is classified as stable when the thickness of the roof of the cave is more than $70 \%$ of the width of the cave. Local researchers such as Abdul Ghani and Goh (2015), Goh et al. (2016a, 2016b, 2016c, 2015a, 2015b), Norbert et al. (2015), Muhammad Fahmi et al. (2016), Tan $(2006,2001)$ were more focused on the stability of slopes of limestone hills, rock falls and rock material strengths. There are less researches and studies on the stability of limestone caves in Malaysia.

The aim of this study was to assess quantitatively, the stability of the cave wall of Gua Damai, Batu Cave 
in Selangor using slope mass rating (SMR) and the cave stability using the Q system for rock mass classification, cave width and thickness of the cave roof.

\section{MATERIALS AND METHODS}

\section{GEOLOGICAL SETTING}

Batu Caves, Selangor is located $13 \mathrm{~km}$ to the north of Kuala Lumpur (Figure 1). Gobbett and Hutchison (1973) reported that the limestone was crystalline, greyish to milky white, thick bedded, stripped marble, saccharoidal dolomite and pure calcatic limestone. The geology (Figure 2) of Kuala Lumpur area consists of sedimentary rocks ranging in age from Middle-Upper Silurian to Mesozoic or younger overlying the older Hawthornden Formation and the Kuala Lumpur Limestone Formation (Gobbett 1965). The limestone in Gua Damai is Silurian in age and is part of Kuala Lumpur Limestone Formations. Kuala Lumpur Limestone Formation was overlying by a younger metasedimentary Kenny Hill Formation composed of quartzite and phylite. Hawthornden Schist Formation composed of interbedded fine grained with dark coloured of rock sequence due to the presence of carbon material and pyrite. The oldest rock formation at Kuala Lumpur is Dinding Schist with the age of Cambrian to Ordovician composing quartz mica schist, calc-silica and schistos conglomerate (Gobbett 1965).

\section{ASSESSMENT OF CAVE STABILITY}

The $\mathrm{Q}$ value is calculated from the rock mass rating (RMR), as suggested by Barton (1995) using (1):

$$
\mathrm{RMR}=15 \log \mathrm{Q}+50
$$

The stability of limestone cave was classified based on recommendations of Waltham (2002) and Waltham and Fookes (2003). The Q value and width of limestone cave width were used to assess the stability (Figure 3). Waltham (2002) and Waltham and Fookes (2003) also suggested that the cave is stable when the thickness of the roof of the cave are more than $70 \%$ of the width of the cave.

\section{ASSESSMENT OF CAVE WALL STABILITY BY USING SLOPE MASS RATING (SMR) METHOD}

The slope mass rating method was proposed by Romana (1995) and used to assess the stability of cave wall. This method comprised of the following components: Uniaxial compressive strength (UCS); Rock quality designation (RQD); Discontinuities spacing; Conditions of discontinuities; Ground water condition; Adjusting factors for joints (F1, F2, F3); and Adjusting factor for excavation (F4).

The uniaxial compressive strength (UCS) of rock material was determined based on the recommendations of the International Society for Rock Mechanics $(1985,1981)$. The value of respective components of (b), (c), (d) and

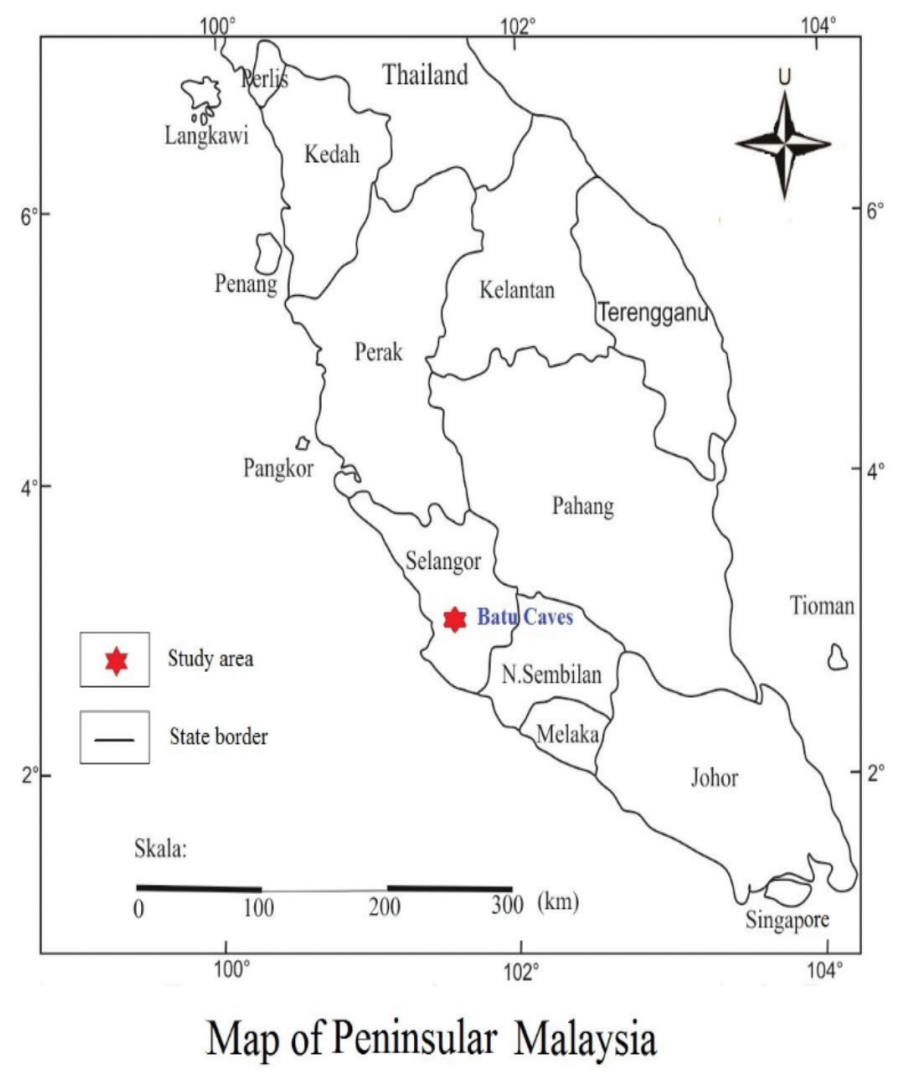

FIGURE 1. The location of study area in Peninsular Malaysia, Malaysia 

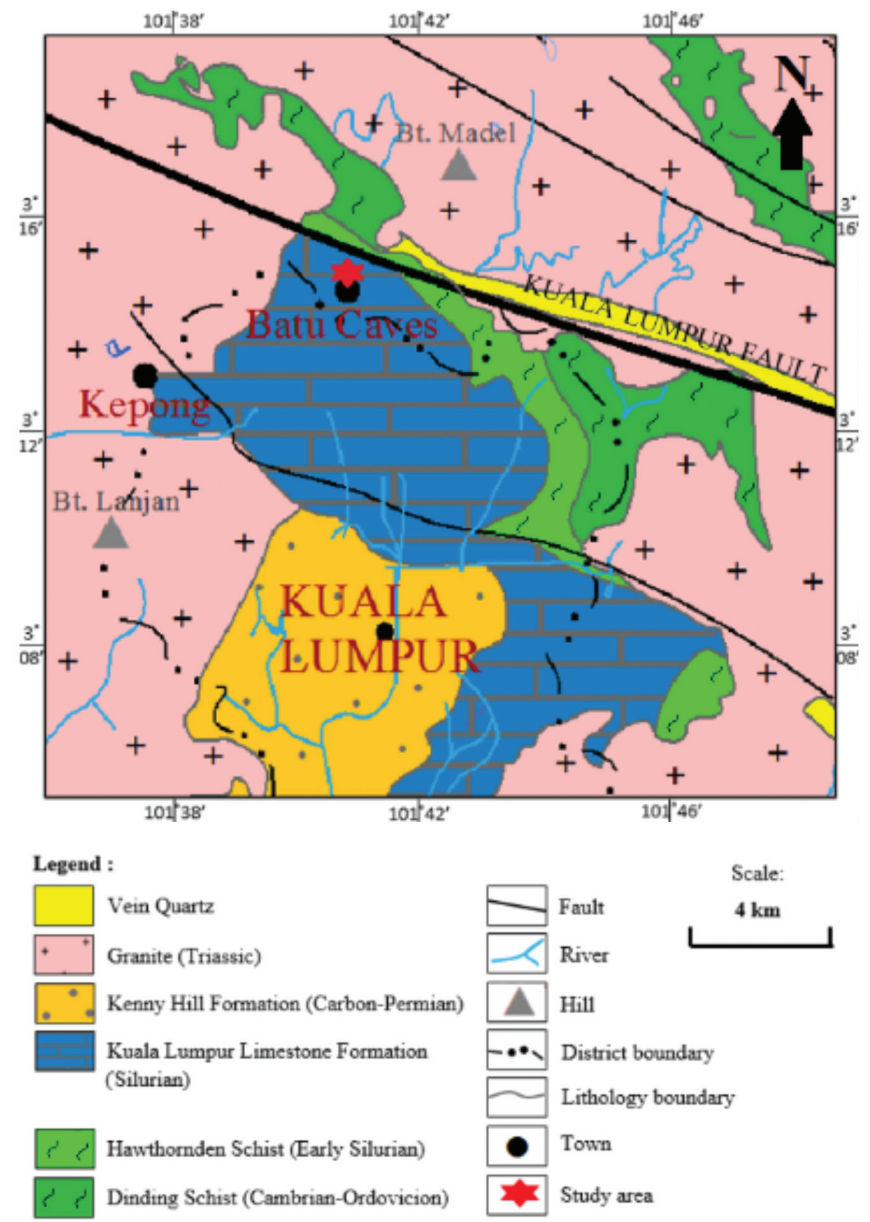

FIGURE 2. Geology map of study area

Source: Modified from Yunus Abd. Razak (2014)

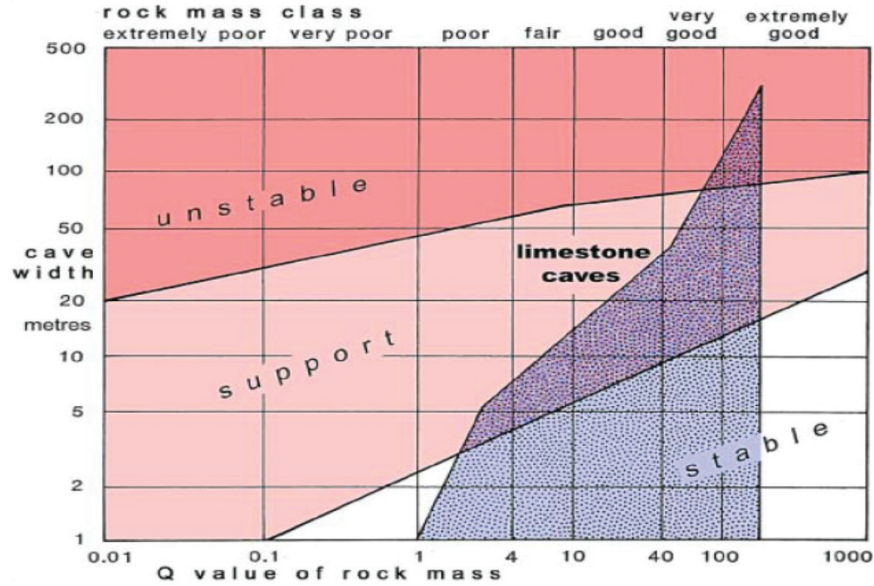

FIGURE 3. Cave stability assessment based on $\mathrm{Q}$ value and cave width Source: Waltham (2002) and Waltham and Fookes (2003)

(d) were determined from scanline discontinuity survey, following suggestions of Ibrahim Komoo dan Ibrahim Abdullah (1983). F1 was the rating for considering the difference of dip direction between joints and slope face. F2 was the rating of dip angle of the respective joint. F3 was the rating for considering the difference of dip angle between joints and slope face. The values of respective components of (a), (b), (c), (d) and (e) are rated based on Romana's (1995) suggestions. The total rating, $\mathrm{RMR}_{\mathrm{b}}$ was (Bieniawski 1989) determined as: 


$$
\begin{aligned}
\operatorname{RMR}_{\mathrm{b}}= & \text { Rating (a) + Rating (b) + Rating (c) }+ \\
& \text { Rating (d) + Rating (e) }
\end{aligned}
$$

The rating for SMR was determined based on (3) as suggested by Romana (1995):

$$
\mathrm{SMR}=\mathrm{RMR}_{\mathrm{b}}+(\mathrm{F} 1 \times \mathrm{F} 2 \times \mathrm{F} 3)+\mathrm{F} 4
$$

\section{RESULTS AND DISCUSSION}

A total of 200 discontinuities readings were obtained for the slopes beneath the cave (Figure 4). The cave was divided into 8 sections and labelled as Sections 1, 2, 3, 4, 5, 6, 7 and 8 (Figure 5). The cave wall was divided into seven portions which were Portions $\mathrm{a}, \mathrm{b}, \mathrm{c}, \mathrm{d}, \mathrm{e}, \mathrm{f}$ and Portion $g$ according to the orientation of the wall (Figure $5)$. Discontinuity survey show that the slope is composed of four (4) major joint sets which are J1, J2, J3, J4 with the dip direction and angle of $110^{\circ} / 73^{\circ}, 325^{\circ} / 87^{\circ}, 243^{\circ} / 39^{\circ}$ and $054^{\circ} / 30^{\circ}$, respectively (Figure 6). The orientations of major joint sets are exhibited in Table 1.

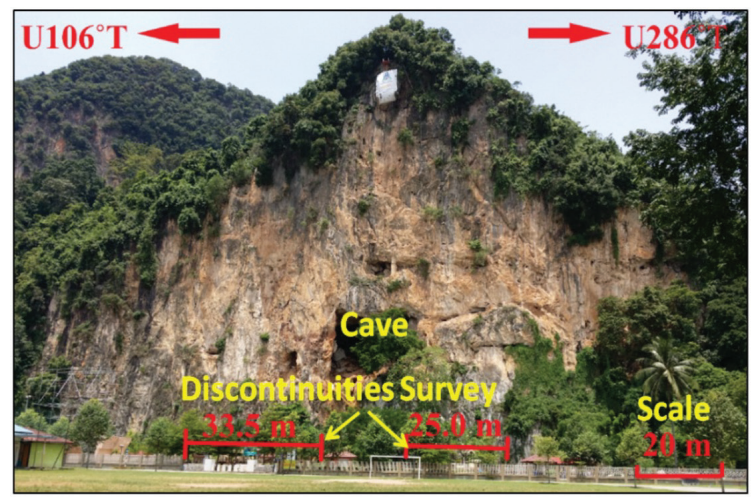

FIGURE 4. Location of discontinuity survey and cave at Gua Damai, Batu Caves, Selangor, Malaysia

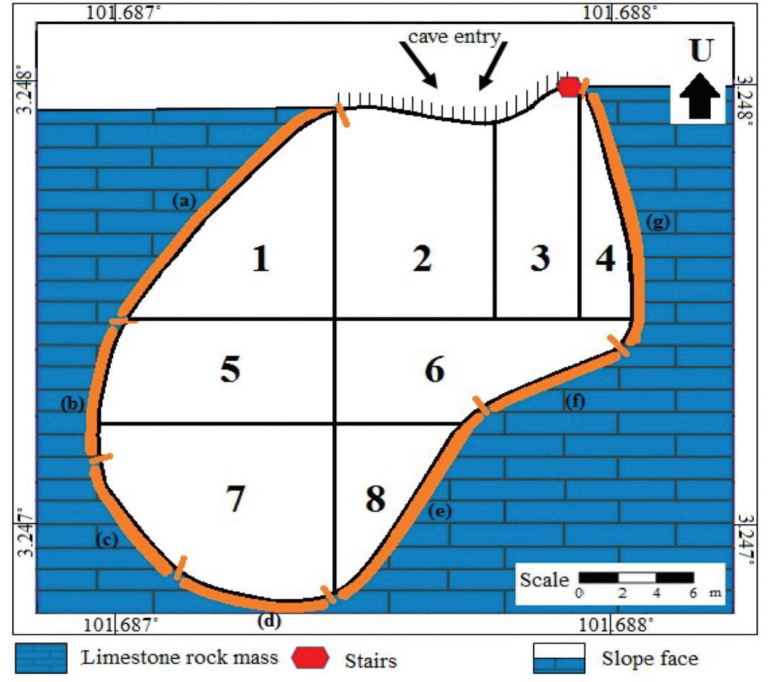

FIGURE 5 . The cave walls and cave cavity were divided into 7 portions (a to $\mathrm{g}$ ) and 8 sections ( 1 to 8 ), respectively, according to the orientation on the cave walls for Gua Damai, Batu Caves, Selangor, Malaysia

The average value of uniaxial compressive strength (UCS) of limestone rock was $30.5 \mathrm{MPa}$, classified as moderate strong based on classification of International Society for Rock Mechanics (1981). The Rock Quality Designation (RQD) value for the limestone slope is $84.8 \%$. Table 2 exhibits the summary of Q ratings for the respective Sections 1, 2, 3, 4, 5, 6, 7 and 8 of Gua Damai, Batu Caves, Selangor, Malaysia. The rating for $\mathrm{RMR}_{\mathrm{b}}$ was 66 . The classification of rock mass rating (RMR) suggested by Bieniawski (1989) for this limestone cave were from fair to good rock mass with the rating of 54 to 66 .

The stability assessment based on relationship between Q system ratings and the cave width according to Waltham (2002) and Waltham and Fookes (2003) shows that the cave

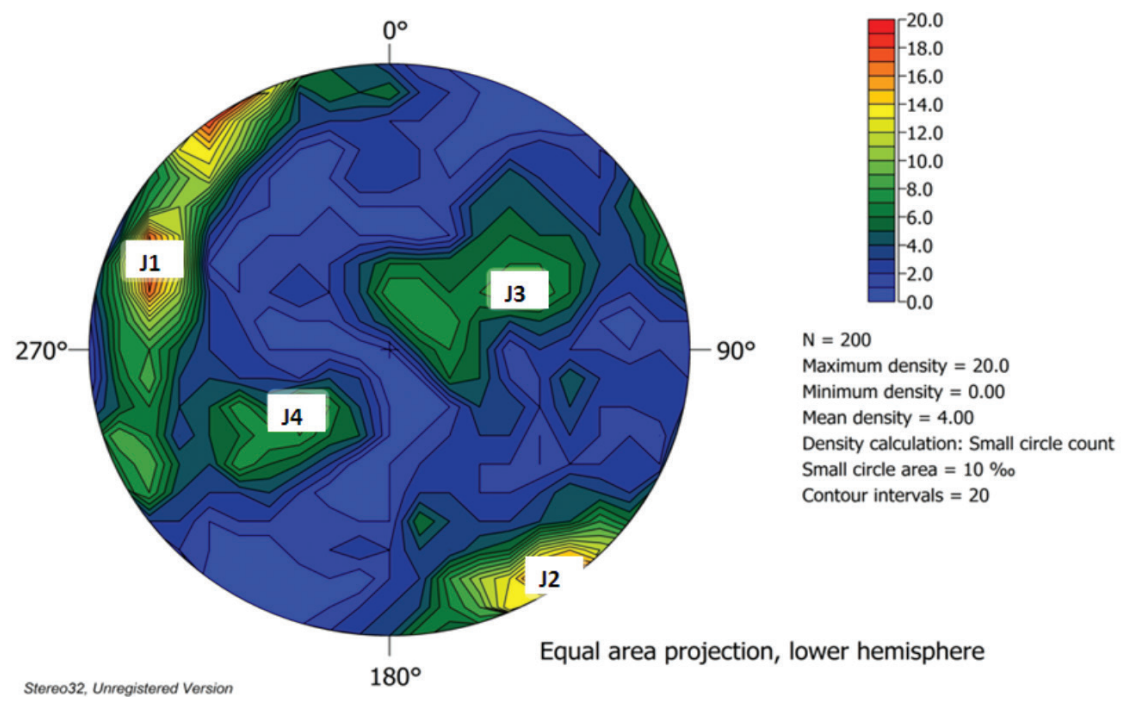

FIGURE 6. Four (4) major joint sets are labeled J1, J2, J3, J4 with the dip direction and angle of $110^{\circ} / 73^{\circ}, 325^{\circ} / 87^{\circ}, 243^{\circ} / 39^{\circ}$ and $054^{\circ} / 30^{\circ}$ for Gua Damai, Batu Caves, Selangor, Malaysia 
TABLE 1. Major Joint sets characteristic at Gua Damai, Batu Caves, Selangor, Malaysia

\begin{tabular}{ccccccc}
\hline Joint sets & Orientation $\left(^{\circ}\right)$ & Spacing $(\mathrm{m})$ & Average Persistence $(\mathrm{m})$ & Aperture & Roughness & Water Condition \\
\hline J1 & $110 / 73$ & 0.98 & 1.79 & very narrow & rough & dry \\
J2 & $325 / 87$ & 1.14 & 1.60 & very narrow & rough & dry \\
J3 & $243 / 39$ & 0.45 & 1.03 & tight & rough & dry \\
J4 & $054 / 30$ & 0.36 & 2.12 & extreme narrow & rough & dry \\
\hline
\end{tabular}

TABLE 2. Q values and classification system calculated from RMR value based on joint orientations for Gua Damai, Batu Caves, Selangor, Malaysia

\begin{tabular}{ccccccc}
\hline Section & $\begin{array}{c}\text { Cave width } \\
(\mathrm{m})\end{array}$ & RMR $_{\mathrm{b}}$ & RMR & $\begin{array}{c}\text { RMR classification } \\
\text { Bieniawski (1989) }\end{array}$ & Q-value & $\begin{array}{c}\text { Q-System classification } \\
\text { (Barton 1974) }\end{array}$ \\
\hline 1 & 8.8 & 66 & 54 & fair & 1.85 & poor \\
2 & 6 & 66 & 56 & fair & 2.51 & poor \\
3 & 4.2 & 66 & 54 & fair & 1.85 & poor \\
4 & 2.5 & 66 & 66 & fair & 1.85 & goor \\
5 & 12.6 & 66 & 66 & good & 11.66 & pood \\
6 & 10.6 & 66 & 54 & fair & 1.85 & poor \\
7 & 12.8 & 66 & 56 & fair & poor \\
8 & 4 & 66 & 54 & fair & 1.51 & r. \\
\hline
\end{tabular}

at Section 4 is stable while the cave in Sections 1,2, 3, 5, 6, 7 and 8 require support (Figure 7). However, the sections of cave that require support are still in a stable condition because of the formation of thick limestone pillars in the middle of the cave that support the cave roof (Figure 8). The ratio of cave roof thickness with cave width was at the range of 2.5-4.0 (Figure 9). This indicated that the cave was stable whereby the ratios were more than 0.7 and the stability were increasing from center of the cave to the wall. This is because the cave was wider and higher in the middle of the cave and smaller near to the cave walls as shown in Figure 10. The higher the cave, the thinner will be the cave roof. This cause lower load and reduces material strength.

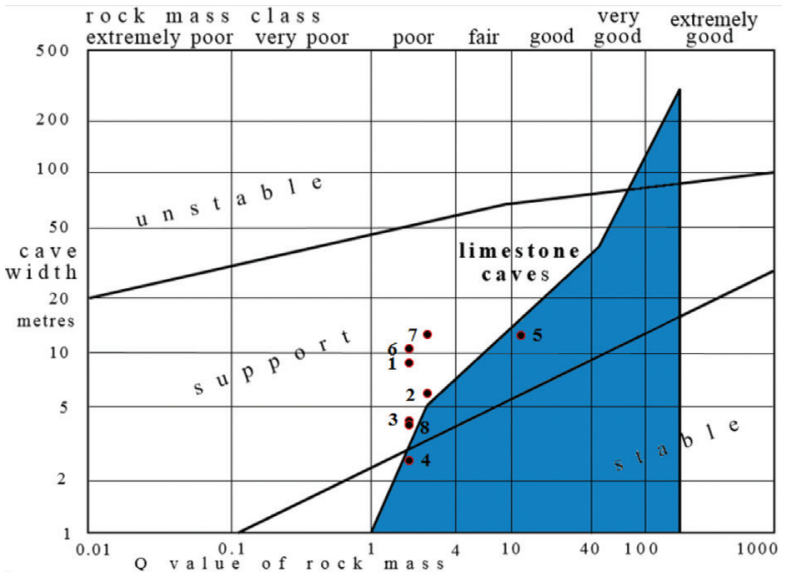

FIGURE 7. The stability assessment of cave based on Q system and cave width for Gua Damai, Batu Caves, Selangor, Malaysia. The diagram shows that section 4 is stable while Section 1,2,3, $5,6,7$ and 8 require support

Source: Modified from Waltham (2002) and Waltham and Fookes (2003)

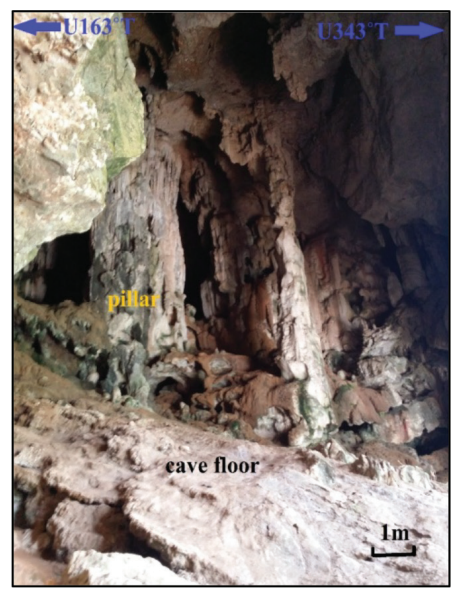

FIGURE 8 . The presence of limestone pillars in the middle of cave act as support and prevent collapse of cave roof

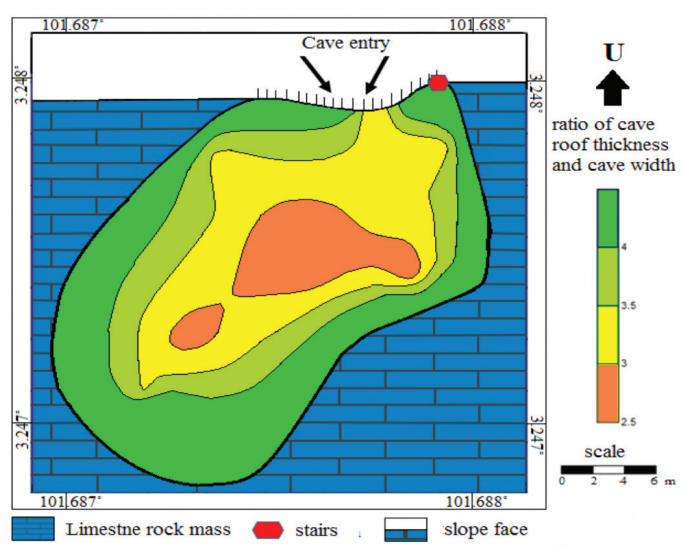

FIGURE 9. Contour map of the ratio of cave roof thickness with cave width for Gua Damai, Batu Caves, Selangor, Malaysia. The higher the ratio, the more stable will be the cave. This indicated that the cave is stable where by the ratios are more than 0.7 


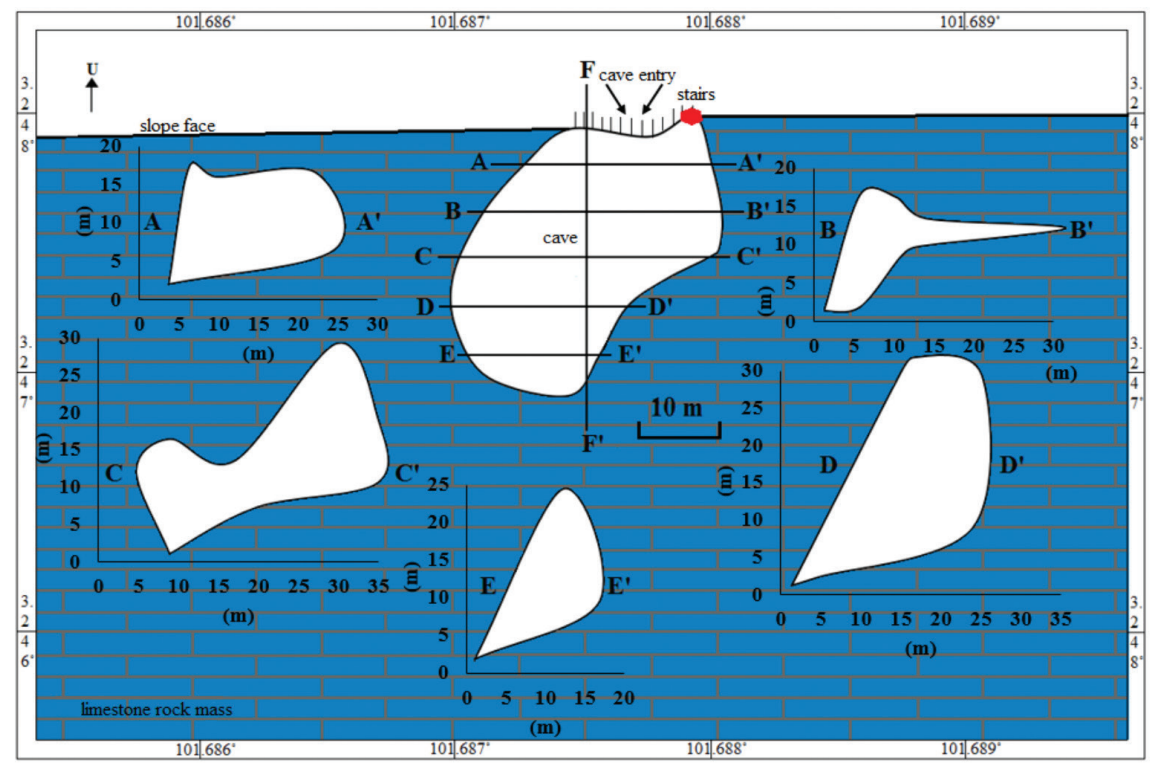

FIGURE 10. Plan view and cross section of the cave at A-A', B-B', C-C', D-D' and E-E' shows that the cave cavity is higher in the middle causing thinner cave roof and lower stability for Gua Damai, Batu Caves, Selangor, Malaysia

The results of the assessment on the walls of the cave based on Slope Mass Rating, SMR (Romana 1985) are exhibited in Table 3. The cave walls at Portions $\mathrm{c}, \mathrm{d}$ and $\mathrm{f}$ are not stable while the walls of Portions $\mathrm{a}, \mathrm{b}$, e and $\mathrm{g}$ are stable. Portions of wall which are not stable plane result from the fact that the orientation of the respective slope face of the cave wall is parallel to the wedge failure plane $\left(051^{\circ} / 59^{\circ}\right)$. Therefore, the walls in Portions c, $\mathrm{d}$ and $\mathrm{f}$ are potentially having wedge failure with the probability of failure of 0.6 .

\section{CONCLUSION}

Figure 11 shows the final stability of cave for Gua Damai, Batu Caves, Selangor, Malaysia. Based on the Q system and the cave width, Sections 4 and 8 of Gua Damai are stable while Sections 1, 2, 3, 5, 6 and 7 required supports. Based on SMR, the cave walls at Portions $\mathrm{c}, \mathrm{d}$ and $\mathrm{f}$ are not stable while Portions a, b, e and $\mathrm{g}$ are stable. Overall, the most stable parts of the cave are Section 4 followed by Sections 5 and 2. Sections 1, 3 and 8 are moderate stable while Sections 6 and 7 have poor stability.

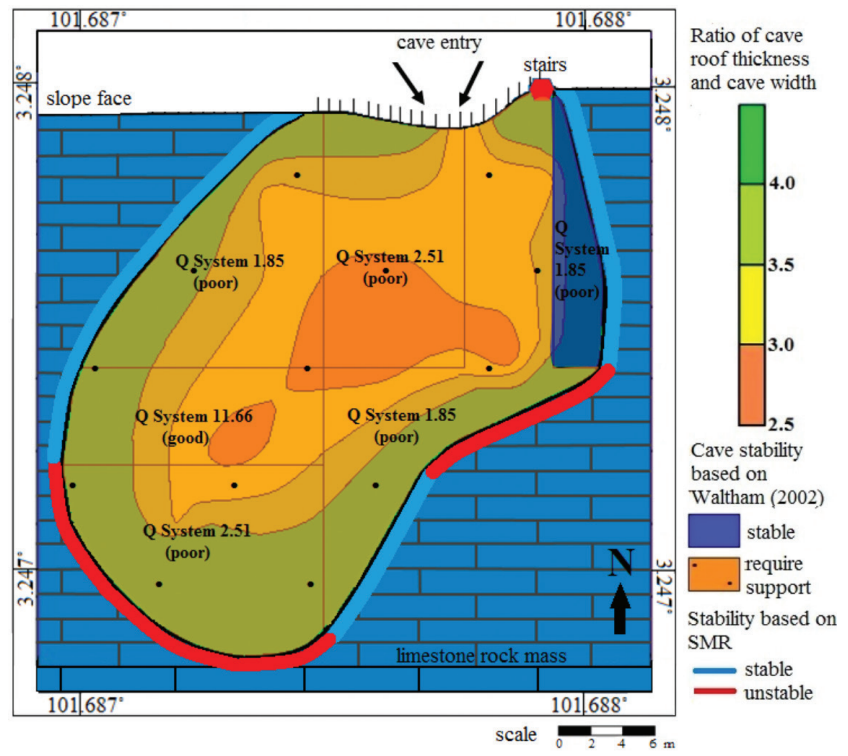

FIGURE 11. Cave stability map based on the ratio of cave roof thickness with cave width, Q system with cave width and stability of cave wall based on SMR assessment for Gua Damai, Batu Caves, Selangor, Malaysia 
TABLE 3. Stability of cave walls based on SMR classification system, Romana (1985) for Gua Damai, Batu Caves, Selangor, Malaysia

\begin{tabular}{|c|c|c|c|c|c|c|c|c|c|c|}
\hline $\begin{array}{c}\text { Portion } \\
\text { of cave } \\
\text { wall }\end{array}$ & $\begin{array}{c}\text { Orientation } \\
\text { of cave wall } \\
\left(^{\circ}\right)\end{array}$ & $\mathrm{RMR}_{\mathrm{b}}$ & $\mathrm{F} 1$ & $\mathrm{~F} 2$ & F3 & $\mathrm{F} 4$ & $\begin{array}{l}\text { Failure } \\
\text { mode }\end{array}$ & SMR & Stability & $\begin{array}{c}\text { Probability } \\
\text { of failure }\end{array}$ \\
\hline a & $138 / 81$ & 66 & - & - & - & - & none & 66 & stable & 0.2 \\
\hline $\mathrm{b}$ & $100 / 68$ & 66 & - & - & - & - & none & 66 & stable & 0.2 \\
\hline $\mathrm{c}$ & $55 / 71$ & 66 & 1.00 & 1.00 & -60 & +15 & wedge $\left(51^{\circ} / 59^{\circ}\right)$ & 21 & unstable & 0.6 \\
\hline $\mathrm{d}$ & $14 / 83$ & 66 & 0.85 & 1.00 & -60 & +15 & wedge $\left(51^{\circ} / 59^{\circ}\right)$ & 30 & unstable & 0.6 \\
\hline $\mathrm{e}$ & $300 / 77$ & 66 & - & - & - & - & none & 66 & stable & 0.2 \\
\hline $\mathrm{f}$ & $336 / 83$ & 66 & 1.00 & 1.00 & -60 & +15 & wedge $\left(51^{\circ} / 59^{\circ}\right)$ & 21 & unstable & 0.6 \\
\hline g & $256 / 64$ & 66 & - & - & - & - & none & 66 & stable & 0.2 \\
\hline
\end{tabular}

\section{ACKNOWLEDGEMENTS}

The authors wish to thank the laboratory staff of the Geology Programme, UKM and the Geosciences Department of Universiti Technology PETRONAS, (UTP). This work has been supported by the Government of Malaysia under the Fundamental Research Grant Scheme FRGS/1/2016/STG08/ UTP/01/1, FRGS/1/2017/WAB08/UKM/02/1 and Universiti Kebangsaan Malaysia internal grant GUP-2016-024. The authors would also like to acknowledge the support of the staff at UKM and UTP as well as the use of facilities at both universities.

\section{REFERENCES}

Abdul Ghani, R. \& Goh, T.L. 2015. A systematic approach for the quantification of rock slope stability. In Engineering Geology for Society and Territory. Volume 2, edited by Lollino, G., Giordan, D., Crosta, G.B., Corominas, J., Azzam, R., Wasowski, J. \& Scirra, N. London: Springer.

Barton, N. 1995. The influence of joint properties in modelling jointed rock masses. 8th ISRM Congress 3(3): 1023-1032.

Bieniawski, Z.T. 1989. Engineering Rock Mass Classifications: A Complete Manual for Engineers and Geologists in Mining, Civil, and Petroleum Engineering. New York: John Wiley $\&$ Sons Inc.

Gobbett, D.J. 1965. The Lower Palaeozoic rocks of Kuala Lumpur, Malaysia. Fed. Mus. J. 9: 67-79.

Gobbett, D.J. \& Hutchison, C.S. 1973. Geology of the Malay Peninsula. New York: Wiley Interscience.

Goh, T.L., Abdul Ghani, R., Nur Ailie, S.S., Norbert, S., Lee, K.E. \& Azimah, H. 2015a. Empirical correlation of uniaxial compressive strength and primary wave velocity of Malaysian schists. Electronic Journal Geotechnical Engineering 20: 1801-1812.

Goh, T.L., Abdul Ghani, R., Nur Ailie, S.S., Norbert, S., Azimah, H. \& Lee, K.E. 2015b. Correlation of ultrasonic velocity slowness with uniaxial compressive strength of schists in Malaysian. Electronic Journal Geotechnical Engineering 20: 12663-12670.

Goh, T.L., Abdul Ghani, R., Nur Ailie, S.S., Azimah, H. \& Lee, K.E. 2016a. Use of ultrasonic velocity travel time to estimate uniaxial compressive strength of granite and schist in Malaysia. Sains Malaysiana 45(2): 185-193.

Goh, T.L., Ainul, M.M.R., Nur Amanina, M., Abdul, G.R., Nur Ailie, S.S. \& Tuan, R.M. 2016b. Rock slope stability assessment using slope mass rating (SMR) method: Gunung Lang Ipoh Malaysia. Scholars Journal of Engineering and Technology (SJET) 4(4): 185-192.

Goh, T.L., Md. Selim, R., Abdul Ghani, R., Nur Ailie, S.S., Azimah, H. \& Lee, K.E. 2016c. Assessment of ultimate bearing capacity based on the Hoek-Brown failure criterion. Sains Malaysiana 45(11): 1603-1607.

Hatzor, Y.H., Talesnick, M. \& Tsesarsky, M. 2002. Continuum and discontinuum stability analysis of the bell shaped caverns at Bet Guvrin, Israel. International Journal of Rock Mechanics \& Mining Sciences 39(7): 867-886.

Ibrahim Komoo \& Ibrahim Abdullah. 1983. Ketakselanjaran dan kaedah pengukuran di lapangan. Sains Malaysiana 12(2): 119-140.

International Society for Rock Mechanics. 1981. Rock characterization, testing and monitoring. In ISRM Suggested Methods, edited by Brown, E.T. Oxford: Pergamon Press.

International Society for Rock Mechanics. 1985. Suggested method for determining point load strength, International Journal Rock Mechanics Mining Sciences and Geomechanics Abstracts 22(2): 51-60.

Muhammad Fahmi, A.G., Norbert, S., Goh, T.L., Tuan Rosli, T.M. \& Abdul Ghani, R. 2016. Kajian ketumpatan lineamen dalam penilaian potensi jatuhan batuan di kawasan Lembah Kinta. Sains Malaysiana 45(12): 1887-1896.

Norbert, S., Muhammad Fahmi, A.G., Azimah, H., Goh, T.L., Abdul, G.R., Noraini, S., Tuan, R.T.M. \& Lee, K.E. 2015. Assesssment of rockfall potential of limestone hills in the Kinta Valley. Journal of Sustainability Science and Management 10(2): 24-34.

Romana, M. 1985. New adjustment ratings for application of Bieniawski classification to slopes. Int. Symp. on the Role of Rock Mechanics ISRM. pp. 49-53.

Tan, B.K. 2001. Engineering geology of limestone in Malaysia. Journal of the Geological Society of China 75(3): 316-324.

Tan, B.K. 2006. Urban geology of Kuala Lumpur and Ipoh, Malaysia. IAEG. p. 24.

Waltham, T. 2002. The engineering classification of karst with respect to the role and influence of caves. Int. J. Speleol. 31(1/4): 19-35.

Waltham, A.C. \& Fookes, P.G. 2003. Engineering classification of karst ground conditions. Quarterly Journal of Engineering Geology and Hydrogeology 38: 101-118.

Yunus Abd. Razak. 2014. Geological Map of Peninsular Malaysia. 9th ed. Kuala Lumpur: Mineral and Geoscience Malaysia. 
Goh Thian Lai, Wong Jia Mang, Nur Amanina Mazlan, Ainul Mardhiyah Mohd Razib \& Azimah Hussin

Geology Program

School of Environmental and Natural Resource Sciences Faculty of Science and Technology

Universiti Kebangsaan Malaysia

43600 UKM Bangi, Selangor Darul Ehsan

Malaysia

Abdul Ghani Rafek

Department of Geosciences

Universiti Teknologi PETRONAS

Bandar Seri Iskandar, 31750 Tronoh, Perak Darul Ridzuan

Malaysia

Ailie Sofyiana Serasa

School of Engineering (Petroleum)

Asia Pacific University of Technology \& Innovation (APU)

Technology Park Malaysia, Bukit Jalil

57000 Kuala Lumpur, Federal Territory

Malaysia
Lee Khai Ern

Institute for Environment and Development (LESTARI)

Universiti Kebangsaan Malaysia

43600 UKM Bangi, Selangor Darul Ehsan

Malaysia

Tuan Rusli Mohamed

Department of Mineral and Geoscience Malaysia Perak Jalan Sultan Azlan Shah

31400 Ipoh, Perak Darul Ridzuan

Malaysia

*Corresponding author; email: gdsbgoh@gmail.com

Received: 18 November 2016

Accepted: 21 June 2017 